Acta vet. scand. $1969,10,48-56$.

From the Research Station for Furbearing Animals, The Veterinary College of Norway, Oslo.

\title{
EXAMINATION OF THE THROMBOCYTE COUNT IN MINK IN CONNECTION WITH ANAEMIA
}

By

Arne Helgebostad and Tordis Röstöen Skogan

It has been observed, in connection with studies of anaemia in mink, that anaemic animals tend to have a quicker haemostasis than normal animals and that blood from anaemic animals coagulates very rapidly. It is interesting in this connection to observe the role played by the thrombocyte count of the blood. Very little research has been carried out with regard to the thrombocyte count in mink. Kubin \& Masson (1948) specify $250,000 / \mathrm{mm}^{3}$ as the normal thrombocyte count in mink. The platelets were counted from slides stained with "Wright Stain".

\section{MATERIAL AND METHODS}

The blood picture of normal and anaemic mink was examined with respect to haemoglobin $(\mathrm{Hb})$ and number of erythrocytes, leucocytes, and thrombocytes. 'The blood samples were drawn from the tail vein without previous anaesthetization. All the animals were treated in the same way and lived in identical environments. Nevertheless, some animals became rather excited during the process of being captured, whereas others were completely calm. The testing techniques were all standardized and all operations were carried out by one person.

Haemoglobin was determined as chlorhemin in a Bausch \& Lomb spectro-photometer according to Cohen \& Smith (1919). The erythrocytes and the leucocytes were counted by means of 
a Ljungberg cytoscope in accordance with the manufacturer's instruction and the counting of platelets was carried out according to Nygaard's method (1933).

A total of 90 mink were examined, including 73 kits from the year concerned, the remaining 17 being adult animals. The types of mink represented in the examination were standard mink (66), sapphire mink (10), and various other mutants.

The majority of the animals were fed with raw coalfish (Gadus virens) as the main source of protein, combined with a basic diet consisting of fats, carbohydrates, and adequate quantities of vitamins A, D, E, and the B complex. Concentrated feeding with raw coalfish usually leads to a microcytic, hypochrome iron deficiency anaemia in a very large percentage of the young animals (Helgebostad 1968).

Twenty-two of the mink fed with raw coalfish, including the adult animals, were positive to Mallen's test. This reaction indicates an increased amount of $\gamma$-globulin in the blood serum, which in most cases in mink is a sign of plasmacytosis. Moderate anaemia is a common symptom in connection with high-grade plasmacytosis.

The large majority of animals with normal haemoglobin values received a diet similar to that mentioned above, but the raw coalfish was replaced by boiled fish. It is known that the anaemic component (s) in raw fish is (are) inactivated by boiling (Helgebostad \& Martinsons 1958).

The remaining 9 mink were given a diet with $40 \%$ of the calorie count supplied in the form of unsaturated fats. Boiled fish and fishmeal were used as the protein source. Such feeding is apt to lead to the development of "yellow fat" disease, with anaemia as a prominent symptom (Helgebostad 1965).

The experiment was carried out in September, October, and November 1967. The normal haemoglobin values in mink at this time of the year vary from 17.0 to $20.0 \mathrm{~g} / 100 \mathrm{ml}$. Haemoglobin values under $12.0 \mathrm{~g} / 100 \mathrm{ml}$ are regarded as pronounced anaemia.

The animals were grouped according to feeding and haemoglobin level (Table 1).

In December, another 16 of the animals from the year in question were selected for control of the thrombocyte count. They were given identical environmental conditions and uniform feeding. At the outset of the experiment, the haemoglobin status of the animals varied from 4.5 to $18.7 \mathrm{~g} / 100 \mathrm{ml}$. 
Table 1.

\begin{tabular}{|c|c|c|c|c|c|}
\hline Group & $\begin{array}{c}\text { Total } \\
\text { number } \\
\text { of } \\
\text { animals }\end{array}$ & $\begin{array}{c}\mathrm{Hb} \\
\mathrm{g} / 100 \mathrm{ml} \\
20.0-17.0\end{array}$ & $\begin{array}{c}\mathrm{Hb} \\
\mathbf{g} / 100 \mathrm{ml} \\
17.0-12.0\end{array}$ & $\begin{array}{c}\mathrm{Hb} \\
\mathbf{g} / 100 \mathrm{ml} \\
12.0-8.0\end{array}$ & $\begin{array}{c}\mathrm{Hb} \\
\mathrm{g} / 100 \mathrm{~m} \\
<\mathbf{8 . 0}\end{array}$ \\
\hline Raw coalfish & 40 & 6 & 11 & 14 & 9 \\
\hline $\begin{array}{l}\text { Raw coalfish with } \\
\text { plasmacytosis }\end{array}$ & 22 & 3 & 4 & 9 & 6 \\
\hline Boiled coalfish & 19 & 12 & 4 & $\left.3^{*}\right)$ & $\mathbf{0}$ \\
\hline Unsaturated fats & 9 & 0 & 4 & 4 & 1 \\
\hline
\end{tabular}

*) These 3 young ones were strongly anaemic before being changed over to feeding with boiled coalfish.

The samples were drawn about 10 a.m., prior to the feeding of the animals. Samples were drawn at fortnightly intervals, 4 times for 12 mink and 3 times for 4 mink.

\section{RESULTS}

In the control animals, the following average values were found: $\mathrm{Hb} 18.2 \mathrm{~g} / 100 \mathrm{ml}$, erythrocytes $10.4 \times 106 / \mathrm{mm}^{3}$, and leukocytes $9,900 / \mathrm{mm}^{3}$. A normal value of $564,000 / \mathrm{mm}^{3}$ was found for the thrombocytes.

It was also found that the number of platelets increased when the haemoglobin value declined to a certain level which varied somewhat in the different animals. Normally, the thrombocyte count was observed to decrease considerably when the Hb level dropped below $4.0 \mathrm{~g} / 100 \mathrm{ml}$.

In certain animals, however, no symptoms of thrombocytosis were observed in connection with subnormal haemoglobin values. This was the case with 8 animals, including 6 which reacted positively to Mallen's test.

The result of the thrombocyte count is illustrated as a step diagram in Fig. 1. It is seen that animals with plasmacytosis did not react with thrombocytosis to the same degree as those with anaemia. At an $\mathrm{Hb}$ level of $5 \mathrm{~g} / 100 \mathrm{ml}$ the average number of platelets was $671,000 / \mathrm{mm}^{3}$, whereas at the same $\mathrm{Hb}$ level, the average for all the animals was $1,307,000 / \mathrm{mm}^{3}$.

The correlation between $\mathrm{Hb} \mathrm{g} / 100 \mathrm{ml}$ and the thrombocyte count is very good (linear correlation $\mathrm{r}=-0.51, \mathrm{P}<0.01$ ). No 


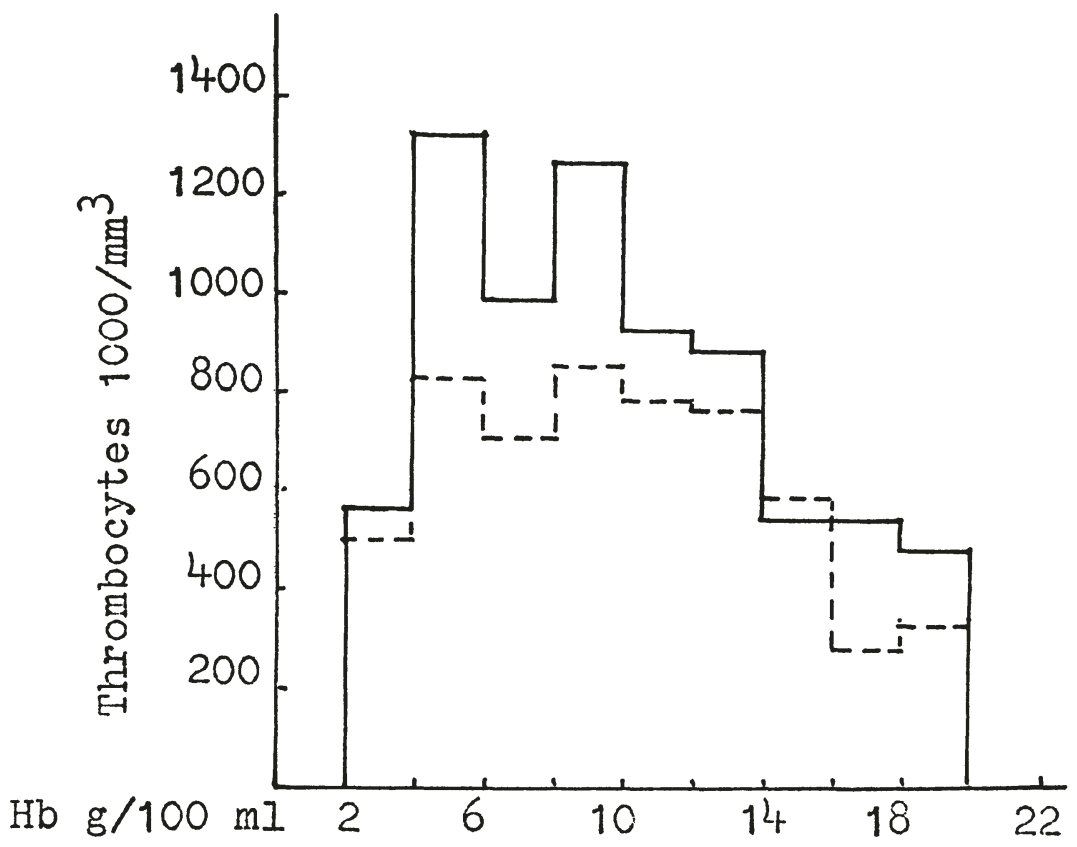

$\mathrm{Figure}$ 1. Variation in number of thrombocytes in relation to $\mathrm{Hb}$ $\mathrm{g} / 100 \mathrm{ml}$.

average number of thrombocytes in 90 mink.

-. - average number of thrombocytes in 22 mink with plasmacytosis.

difference could be demonstrated between young and adult animals.

Fig. 2 shows the variation in the numbers of erythrocytes and leukocytes according to the haemoglobin values. This is in agreement with previous experiments in connection with fishinduced anaemia (Helgebostad \& Martinsons 1958). The correlations between $\mathrm{Hb}$ and erythrocytes $(\mathrm{r}=0.56)$ and between $\mathrm{Hb}$ and leukocytes $(\mathrm{r}=-\mathbf{0 . 3 2})$ are significant. A slightly significant difference between the regressions of the groups was found, but there was no difference between the various types of mink.

Of the 16 animals selected in December, 11 showed an unchanged $\mathrm{Hb}$ level throughout the experiment. The thrombocyte count also remained relatively constant and, indeed, at the expected level compared with the previous experiments. In the remaining animals the haemoglobin values varied somewhat, but the thrombocyte count varied inversely with the $\mathrm{Hb}$. Only 


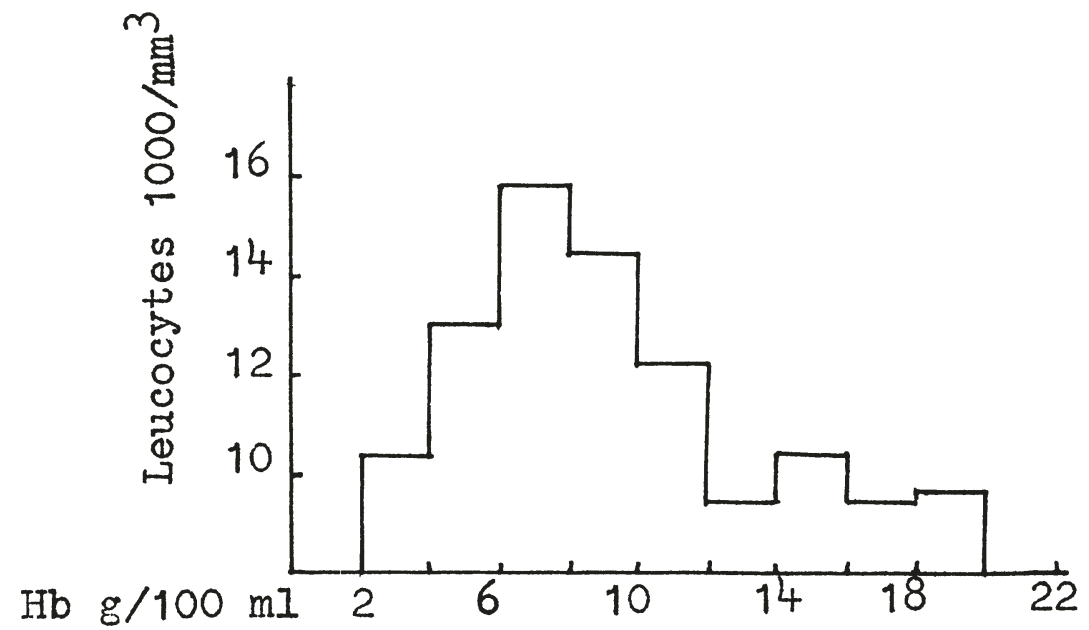

F ig u r e 2 a. Variation in leucocytes in relation to $\mathrm{Hb} \mathrm{g} / 100 \mathrm{ml}$.

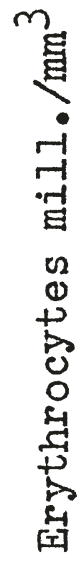

$\mathrm{Hb} \mathrm{g} / 100 \mathrm{ml}$

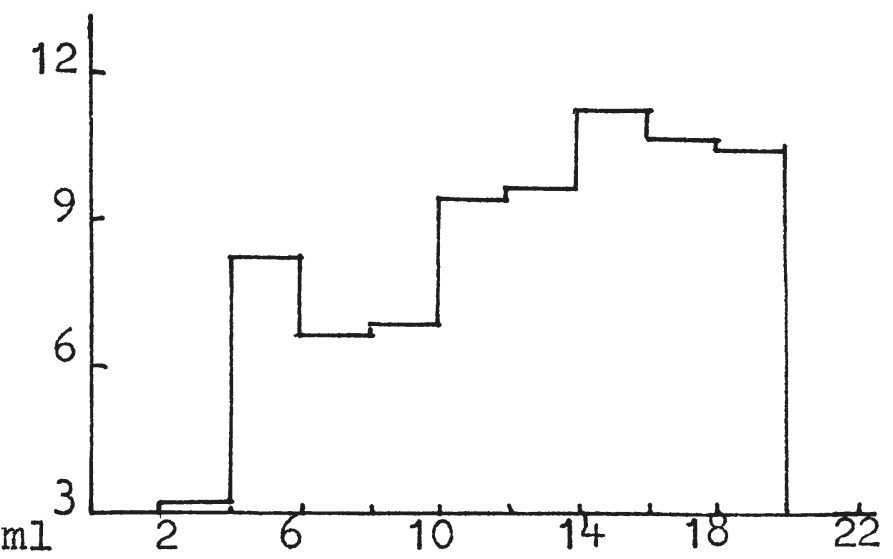

$\mathrm{F}$ ig u r e $2 \mathrm{~b}$. Variation in erythrocytes in relation to $\mathrm{Hb} \mathrm{g} / 100 \mathrm{ml}$.

in a single animal was found a low number of platelets compared to the $\mathrm{Hb}$ value, viz. $371,000 / \mathrm{mm}^{3}$ and $11.8 \mathrm{~g} / 100 \mathrm{ml}$, respectively, and this situation remained unchanged throughout the experiment. 
Blood samples were also drawn twice from 4 animals with a one-hour interval, and the number of platelets was unchanged both times in all these animals.

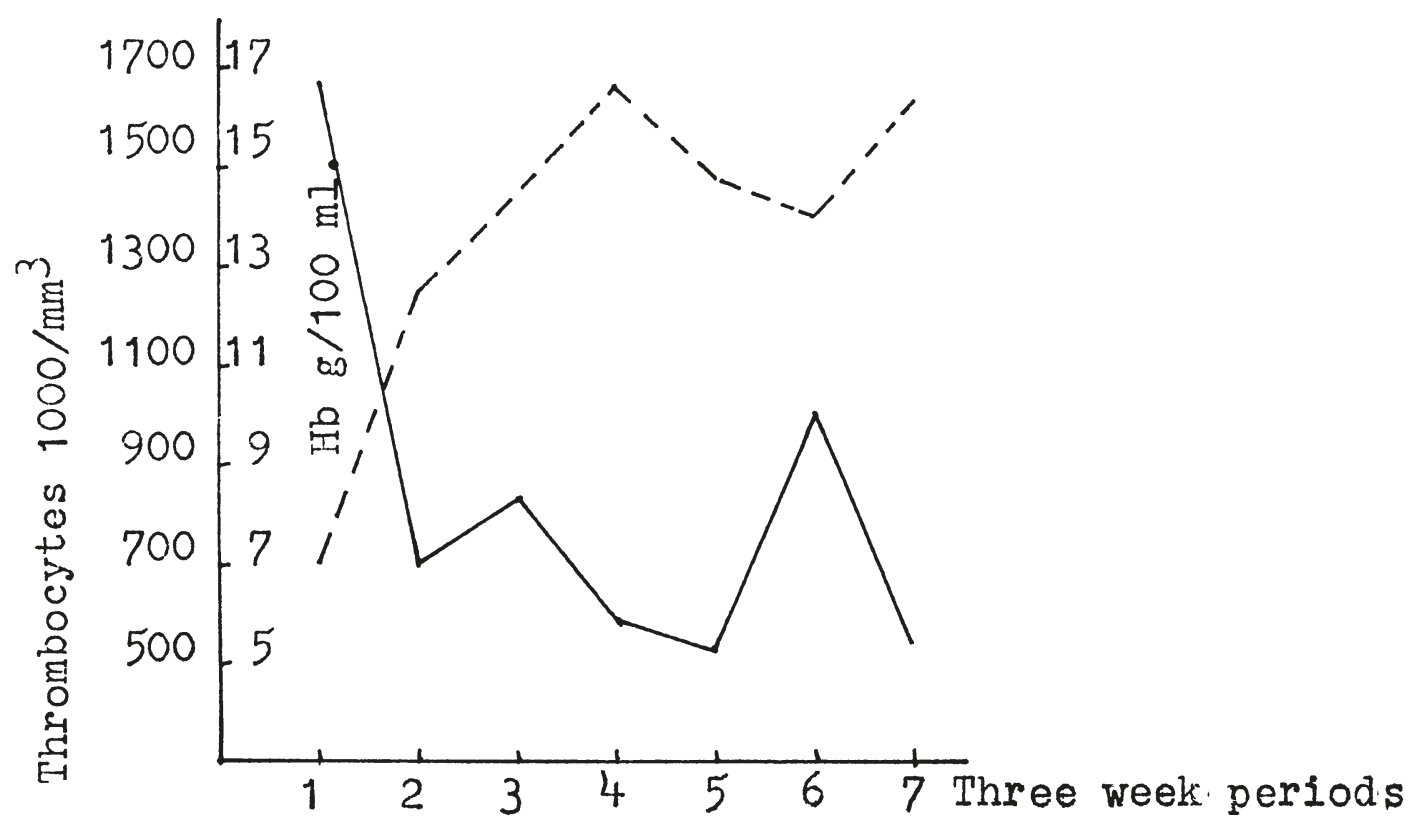

$\mathrm{Fig}$ u r e 3. Variation in $\mathrm{Hb}$ and thrombocytes in mink $178 \mathrm{P}$ from September 28, 1967 to February 14, 1968.

- thrombocytes. - - - Hb $\mathrm{g} / 100 \mathrm{ml}$.

From 1 animal, viz. $178 \mathrm{P}$, a total of 7 samples were drawn during the period September 28, 1967 to February 14, 1968. The results, presented in Fig. 3, clearly demonstrate how the thrombocyte count varies in relation to the haemoglobin status of the animal concerned.

\section{DISGUSSION}

On the basis of a standard material with regard to $\mathrm{Hb}$, erythrocytes, and leukocytes, the authors have endeavoured to arrive at a normal value for the thrombocyte count in mink. The blood constants found coincide well with previous research results by Kennedy (1935), Kubin \& Masson (1948), Helgebostad \& Martinsons (1958). Generally, however, the authors found a 
considerably higher thrombocyte count, viz. $564,000 / \mathrm{mm}^{3}$ than did Kubin who states $250,000 / \mathrm{mm}^{3}$ as normal in mink. But different methods of counting the thrombocytes have been employed.

Normally, mink are rather excited when captured. Bieguszewski \& Chudy (1963) found higher haemoglobin and haematocrit values and higher number of erythrocytes in mink that were strongly excited before the blood sampling than in mink anaesthetized in advance. In cats, Field (1930) observed an increase in the number of erythrocytes and thrombocytes after a stress period of $3 \mathrm{~min}$. The increase amounted to 150,000 platelets $/ \mathrm{mm}^{3}$ above normal level.

With a view to determining whether 2 successive blood samplings differed significantly, 2 samples were drawn from 4 mink with a one-hour interval for counting the platelets. Both counts yielded identical results. The irritation caused to the mink by 2 capturings in the course of $1 \mathrm{hr}$. appeared to have played no important role for a possible increase in the thrombocyte count in the blood of the mink.

Very few data are available in the literature about the state of thrombocytes during anaemia in animals. Schalm (1965) states that in connection with acute loss of blood the number of thrombocytes increases instantly in order to reduce the period of bleeding. Lack of vitamin $B_{12}$ or folic acid in dogs leads to thrombocytopenia.

Wintrobe (1961) states that in human beings the number of platelets increases immediately in connection with a posthaemorrhagic anaemia. The increase takes place in the course of the first hour. Wintrobe further writes that anaemia caused by iron deficiency usually will result in the formation of small platelets but in normal numbers. Chronic haemorrhages may lead to a slight degree of thrombocytopenia. Pronounced thrombocytosis often occurs in connection with chlorosis.

The authors found a marked degree of thrombocytosis in connection with anaemia in mink. Severe cases of anaemia lead to a very high thrombocyte count, in 1 animal as high as $1,900,000 / \mathrm{mm}^{3}$. The same mink showed $\mathrm{Hb} 8.8 \mathrm{~g} / 100 \mathrm{ml}$, red blood corpuscles $8.6 \times 10^{6} / \mathrm{mm}^{3}$, and white blood corpuscles $37,500 / \mathrm{mm}^{3}$. In cases of exceptionally low $\mathrm{Hb}$, i.e. $4.0 \mathrm{~g} / 100 \mathrm{ml}$ and lower, the number of thrombocytes is radically reduced, the 
animals then being very weak and apparently not reacting in the same way as mink with higher $\mathrm{Hb}$ values.

The described cases of anaemia are characterized as a microcytic, hypochrome iron deficiency anaemia. The ratio between haemoglobin and erythrocytes is reduced in accordance with reduced haemoglobin status. An inverse relation is brought about between haemoglobin/erythrocyte count and the thrombocyte count. There are indications that this type of anaemia leads to release of agents stimulating both the erythrocyte production and the thrombocyte production. Further investigations of this problem are being made.

\section{REFERENCES}

Bieguszewski, H. \& J. Chudy: Morphology of the mink's blood. Med. weteryn. $1963,19,165-168$.

Cohen, B. \& A. H. Smith: The colometric determination of haemoglobin. J. biol. Chem. 1919, 39, 489-496.

Field, M. E.: The effect of emotion on the blood - platelets count. Amer. J. Physiol. 1930, 93, 245.

Helgebostad, A.: Hvordan forskjellige fettstoffer i fóret innvirker på pelskvaliteten. (How various fats in the feed affect the fur quality). Norsk Pelsdyrbl. 1965, 39, 348-351.

Helgebostad, A.: Anemi hos mink. (Anemia in mink). Nord. Vet.-Med. 1968, 20, 161-172.

Helgebostad, A. \& E. Martinsons: Foringsanemi hos mink. (Nutritional anaemia in mink). VIII. Nord. Vet.-möte, Helsingfors 1958, 264 $-273$.

Kennedy, A. H.: Cytology of the blood of normal mink and raccoon. Canad. J. Res., E 1935, 12, 484-494.

Kubin, R. \& M. M. Masson: Normal blood and urine values for mink. Cornell Vet. 1948, 38, 79-85.

Nygaard, K. K.: A direct method of counting platelets in oxalated plasma. Proc. Mayo Clin. 1933, 8, 365-370.

Schalm, O. W.: Veterinary Hematology. 2. Ed., California 1965, 318$321,380-393$.

Wintrobe, M. M.: Clinical Hematology. 5. Ed., Philadelphia 1961, 248$285,745-746$.

\section{SUMMARY}

By comparing the blood picture in normal mink with the blood picture in mink suffering from iron deficiency anaemia, an explicit thrombocytosis was found in the anaemic animals.

A significant correlation existed between $\mathrm{Hb} \mathrm{g} / 100 \mathrm{ml}$ and the number of thrombocytes (linear correlation $r=-0.51, P<0.01$ ). 
The thrombocyte count varied inversely with $\mathrm{Hb}$, and an inverse relation was obtained between the haemoglobin/erythrocyte number and the thrombocyte count.

\section{ZUSAMMENFASSUNG \\ Untersuchungen über die Thrombozytmenge bei Nerzen \\ im Anschluss an Anämie.}

Bei einem Vergleich der Blutbilder von gesunden Nerzen mit den Blutbildern von Nerzen mit Eisenmangelanämie wurde bei Tieren mit Anämie eine bedeutende Thrombozytose festgestellt.

Es besteht eine sichere Korrelation zwischen $\mathrm{Hb} \mathrm{g} / 100 \mathrm{ml}$ und der Thrombozytmenge (lineare Korrelation für $\mathbf{r}=\div 0,51, \mathrm{P}<0,01$ ).

Die Thrombozytmenge variierte umgekehrt proportional mit dem $\mathrm{Hb}$, und ein umgekehrtes Verhältnis zwischen Hämoglobin/Erythrozytmenge und Thrombozytmenge wurde festgestellt.

\section{SAMMENDRAG}

Undersökelser over trombocyttallet hos mink $i$ tilslutning til anemi.

Ved en sammenligning af blodbildet hos normal-mink med blodbildet hos mink med jernmangelanemi, har en funnet en tydelig trombocytose hos dyr med anemi.

Det er en sikker korrelasjon mellom $\mathrm{Hb} \mathrm{g} / 100 \mathrm{ml}$ og antall trombocytter (lineær korrelasjon for $\mathrm{r}=-0,51, \mathrm{P}<0,01$ ).

Trombocyttallet varierte omvendt proporsjonalt med $\mathrm{Hb}$, og en fikk en invers relasjon mellom hemoglobin/erytrocyttallet og trombocyttallet.

(Received August 13, 1968). 